\title{
Equality in the making? : Roma and Traveller Minority Policies and Basic Education in Three Nordic Countries
}

\section{Helakorpi, Jenni}

2020-01-02

Helakorpi , J , Lappalainen , S \& Mietola , R 2020 , ' Equality in the making? Roma and Traveller Minority Policies and Basic Education in Three Nordic Countries ' , Scandinavian Journal of Educational Research , vol. 64 , no. 1 , pp. 52-69 . https://doi.org/10.1080/00313831.2018.1485735

http://hdl.handle.net/10138/312054

https://doi.org/10.1080/00313831.2018.1485735

unspecified

acceptedVersion

Downloaded from Helda, University of Helsinki institutional repository.

This is an electronic reprint of the original article.

This reprint may differ from the original in pagination and typographic detail.

Please cite the original version. 
Equality in the making? Roma and Traveller minority policies and basic education in three Nordic countries

Jenni Helakorpi (Corresponding author), Institute of Educational Sciences, University of Helsinki jenni.helakorpi@helsinki.fi

Sirpa Lappalainen, Institute of Educational Sciences, University of Helsinki sirpa.lappalainen@helsinki.fi

Reetta Mietola, Department of Social Research, University of Helsinki reetta.mietola@helsinki.fi 


\begin{abstract}
The article examines policies intended to promote the basic education of Roma and Traveller minorities in Finland, Sweden and Norway by analysing key national Roma and Traveller policy $(\mathrm{N}=5)$ and education policy documents $(\mathrm{N}=3)$. Analysis shows how the Finnish, Swedish and Norwegian Roma policies translate the general policy aims of improving the social positioning of people identifying as Roma consistently into policy measures responding to the special needs of Roma pupils. These policy measures are validated by problem representations regarding Roma parents and families. All the policies also problematise the relationship between Roma and Traveller cultures and schools. It is argued that the focuses of the current policy measures constrain opportunities for a change in terms of equality.
\end{abstract}

Keywords: Roma, Travellers, minority policies, basic education policies 


\section{Introduction}

Roma and Traveller groups continue to be marginalised in various ways in societies throughout Europe. ${ }^{1}$ The Nordic countries are no exception. However, like many other European countries, Finland, Sweden and Norway have started to emphasise that Roma and Traveller groups belong to the nation-states and, as the only Nordic countries, they have granted national minority status to particular Roma and Traveller groups. ${ }^{2}$ Still, welfare gaps for people identifying as Roma or Travellers have been found to persist in each of these countries. Roma and Traveller groups occupy disadvantaged positions in education, labour markets, housing, health care and public life (Muižnieks 2015; MSAH 2009; NOU 2015; SOU 2010; Weiste-Paakkanen, Martelin, Koponen, Koskinen \& Linnanmäki 2014). Moreover, discrimination against the Roma and Travellers has been found to be widespread (HL-senteret 2012; NDO 2014; Rosvoll \& Bielenberg 2012; SOU 2010; SOU 2016).

Finland, Sweden and Norway have policies intended to improve the situation of the Roma and Travellers. The countries collaborate with each other, and have exchanged knowledge during the formulation of the current policies (AoI 2009; MSAH 2016; SOU 2009). Education plays a major role in both the international and national Roma and Traveller policies since the promotion of education is perceived to advocate equality, inclusion and human rights (e.g., CoE 2000; European Commission 2011; OSCE 2003; UN 2013). Good educational outcomes are

\footnotetext{
${ }^{1}$ The term 'Roma' is often used as an umbrella term for all Roma groups, including Travellers. However, to use the term Roma in the Norwegian context excludes the Traveller minority (see the national minority definitions below). In Sweden, the term Roma includes the Traveller minority. In the text, we will use the terms according to each country's national minority definition.

${ }^{2}$ Finland has ratified CoE Treaty 157 on the Framework Convention for the Protection of National Minorities, and one of the minorities that Finland reports on to the Council of Europe is the Roma. In Finnish, a term equivalent to "national minority" is "old minority". However, for clarity in the text, we use the term national minority in the Finnish context as elsewhere.
} 
entrusted to lead to upward socio-economic mobility which will eventually lead to equality (CoE 2000; European Union 2012; OSCE 2003).

In this article, the policies which consider national minority Roma and Travellers in the context of basic education (i.e., compulsory school) are analysed cross-culturally in three Nordic countries: Finland, Sweden and Norway. ${ }^{3}$ Our analysis moves beyond the national level because the domestic policies are entangled with the internationalisation of minority rights and Roma and Traveller policies (Alexiadou 2017; Brubaker 1996; Kymlicka 2007; Vermeersch 2006). We ask how the measures in national Roma and Traveller policies and education policies frame and identify problems related to Roma, Travellers and basic education. Our approach is twofold: firstly, we analyse national Roma and Traveller policies, focusing especially on the measures that are promoted to improve the situation of Roma and Travellers in basic education. Secondly, we analyse the ways Roma and Travellers are discussed in the national basic education curricula. Our analysis considers the policies productive since they enable a certain kind of change by framing how problems, ideals and solutions are understood (Bacchi 2000; 2009; 2010). We analyse the ways the national policy measures produce understanding of the problems which need to be tackled and the ways Roma and Traveller groups are perceived.

The article is structured as follows: first, the national policies concerning Roma and Traveller minorities in Finland, Sweden and Norway are presented in the context of internationalization of minority rights and Roma and Traveller policies. This is followed by a description of basic education policies and how Roma and Traveller national minorities are framed in current basic education legislation in Finland, Sweden and Norway. Next, the method of analysis and the data are introduced. The results are presented in three sub-chapters focusing on different aspects

\footnotetext{
${ }^{3}$ All three countries are member states in Council of Europe. Unlike Finland and Sweden, Norway is not a member state of European Union.
} 
of the analysed policy measures. Finally, the concluding chapter will discuss the main findings in relation to the key national and international minority policy targets and the impact of our analysis on current policy work.

\section{National minority Roma and Traveller policies in Finland, Sweden and Norway}

"Roma and Traveller" (or often just "Roma") is an umbrella term covering many Roma and Traveller groups. They form the largest and one of the oldest ethnic groups in Europe, and some Romani activists have claimed the right to be called a nation (Roma Nation and Travelers; Vermeersch 2006; Yuval-Davis 2011, p. 81). However, there is diversity in how people identifying Roma or Traveller perceive the transnational "Roma-ness and Traveller-ness" and the joint claims (e.g. Bunescu 2014; Herakova 2009; Vermeersch 2006). Roma and Travellers have been and still are persecuted in Europe (Brearley 2001) and there are current national projects throughout Europe which seek to exclude Roma and Travellers and posit them as people "that exist everywhere but belong nowhere" (Yuval-Davis, Wemyss and Cassidy 2017, pp. 5-6). In this section, we describe the ways Roma and Traveller groups and their positions are currently defined by the policies of the international (governmental) organisations and the policies of the Finnish, Swedish and Norwegian nation-states. We do not address the multiplicity and complexity of the lived identities of individuals.

Since the fall of communism in Europe, the Roma and Traveller minorities have been perceived "in terms of their European belonging and minority identity" (van Baar 2012a, p. 287), and discourses of ethnic minority protection have become commonplace (Vermeersch 2008; 2012). In the 1990s, several European countries ratified the Council of Europe Treaty 157, the Framework Convention for the Protection of National Minorities (CoE Treaty 157), and 
granted their Roma and Traveller groups national minority status. Several countries also ratified the European Charter for Regional or Minority Languages (CoE ETS No. 148), by which they acknowledged Romani dialects and variations as minority languages in their respective countries. These two legal instruments are intertwined, aiming to protecting national minorities and regional and national minority languages. The instruments are part of human rights protection in Europe, and are argued to contribute to European democracy and cultural diversity (CoE ETS No. 148, pp.1) as well as to stability, democratic security and peace (CoE Treaty 157, pp.1). The Nordic countries,except for Iceland, ratified these legal instruments. However, only Finland, Sweden and Norway acknowledged particular Roma and Traveller groups and their languages according to the treaty and the charter.

Ratification led to new definitions of the groups and their relations within the nation-states. In Finland, the national Roma minority includes one Roma group: Finnish Roma/Kale. It is estimated that today there are approximately 9,000-10,000 Finnish Roma in Finland (Rajala \& Blomerus 2015), ${ }^{4}$ who generally speak Finnish as their mother tongue. In Sweden, the definition of the national Roma minority includes several Roma groups, which are usually described by the period of their arrival in Sweden: Travellers, Swedish Roma, Finnish Roma/Kale, NonNordic Roma and recently-arrived Roma. ${ }^{5}$ It has been estimated that there are around 50,000 people who identify as Roma in Sweden (SOU 2010). Their mother tongue in Sweden varies from different Romani dialects to Swedish, Finnish and even other languages (Bijvoet \& Fraurud 2007). Two national Roma minorities were distinguished in Norway in the process of defining national minorities: Roma and Travellers (Norwegian Travellers are also known as Romani/Romani people/Tater). It is estimated that there are around 700 Roma and around 4,000-10,000 Travellers in Norway (Engebrigtsen 2015; Muižnieks 2015). The mother tongue

\footnotetext{
${ }^{4}$ The numbers are estimates, as there are no statistics on ethnic grounds in these countries.

${ }^{5}$ The groupings contain multiple subgroups.
} 
of the Norwegian Roma is usually a dialect of Romani, whereas many people identifying as Travellers speak Norwegian as their mother tongue (AoI 2009; NOU 2015). Finnish and Norwegian definitions mean that for instance the Roma who migrated from the former Yugoslavia to Finland and Norway in the 1990s are not defined as part of the Roma national minority, whereas in Sweden they are. Thus, "national-minority-ness" is also used for establishing distinctions within and between Roma and Traveller groups (Yuval-Davis, Varjú, Tervonen, Hakim \& Fathi, 2017).

The way "national-minority-ness" is translated into laws, policies and practices partly conditions the ways people identified as Roma and Travellers are perceived within societies and institutions, such as schools. In Finland, the right of different language and cultural groups to maintain and develop their language and culture was written into the Finnish constitution in the year 2000. The Sami and Roma were named as examples of such groups (1999/713 17§, ss. 3). Finland does not, however, have any general policy statement concerning national minorities. In the Swedish act concerning national minorities and minority languages (2009:724), Roma are defined as one of Sweden's five national minorities. A specific language act identifies Romani as a minority language in Sweden (2009:600). The Swedish government formulated a policy on national minorities in 2008 (proposal 2008/09:158). Norway, unlike Finland and Sweden, does not have specific national legislation to supplement CoE Treaty 157 and Charter 148 in relation to Roma and Traveller minorities. In the year 2000, the government tabled a white paper in the Norwegian parliament entitled National minorities in Norway about state policy on Jews, Kvens, Roma, Travellers and Forest Finns $;^{6}$ the paper still works as a policy guidance document on national minorities in Norway.

\footnotetext{
${ }^{6}$ Translation by authors from "Nasjonale minoritetar i Noreg - Om statleg politikk overfor jødar, kvener, rom, romanifolket og skogfinnar”.
} 
Even though Roma and Traveller groups and group relations are impacted by their national minority status, it is also characteristic of European policies to perceive Roma and Travellers as in need of special attention (Vermeersch 2006, pp. 187-200). Huub van Baar (2012a, 287) has characterized the recent policy development for Roma and Travellers in Europe as "a unique case, as no other minority has recently become the target of such processes of Europeanization, nor of the involved large-scale social inclusion programs." In fact, in addition to the aforementioned Treaty 157 and Charter 148, the Council of Europe has also formulated a declaration specifically concerning the Roma, and is undertaking multiple projects on Roma issues (CoE 2010; CoE: Roma and Travellers; CoE 2016). The Organisation for Security and Co-operation in Europe has an Action Plan on Improving the Situation of Roma and Sinti within the OSCE Area (OSCE, 2003). The United Nations do not have their own Roma inclusion policy but the organization characterizes their work in supporting Roma inclusion as extensive (UN 2013). The World Bank has been involved in Roma inclusion/integration in many ways and has for instance produced a Handbook for Improving the Living Conditions of Roma at the Local Level (2015) together with the European Commission. Additionally, the European Union has an EU Framework for National Roma Integration Strategies up to 2020, a coordinated policy process which aims to impact national policies. Member States are committed to develop, implement and monitor National Roma Integration Strategies (NRIS) (European Commission 2011). Regardless of these numerous international policies and efforts, the European Roma and Traveller policies have been criticised for being unable to address inequalities and discrimination or to advance transformative change (Araújo 2016; Gobbo 2015; Helakorpi, Lappalainen and Sahlström in press; Nordberg 2015; O’Nions 2015; RodellOlgaç 2013; van Baar 2012b). 
Finland, Sweden and Norway have specific policy processes relating to national minority Roma and Traveller groups. The policies are impacted by both internationalization of minority rights and European Roma inclusion/integration efforts. The Finnish and Swedish policy processes have more continuity and articulate coordination than the Norwegian policies. In Finland, a national Roma policy was formulated in 2009 , the key document being The proposal of the working group for a national policy on Roma. This policy document also serves as the Finnish NRIS for the European Union Framework. In Sweden, The coordinated long-term strategy for Roma inclusion 2012-2032 is the top policy document steering national minority Roma policy. This Roma policy is the Swedish NRIS. In Norway, there is currently no clear national policy statement specifically concerning Roma or Traveller policy. The aforementioned white paper National minorities in Norway - about state policy on Jews, Kvens, Roma, Travellers and Forest Finns is the top document on Roma and Traveller national minorities. However, Action plan for improvement of the living conditions of Roma in Oslo was released in 2009. The action plan has already been evaluated and found to be ineffective (Tyldum \& Friberg 2014), but a new operative policy has not been written for the Roma. A green paper on Traveller policy entitled Assimilation and resistance in Norwegian policies towards Tater/Romani people from 1850 to the present (Noregs offentlege utredninger, NOU) was also released in 2015. At the end of autumn 2016, the hearing rounds of the green paper ended, but it is unclear whether this will be converted into a national policy.

\section{Roma, Travellers and basic education}

As already described, education has a vital role in the field of Roma and Traveller policies. Our focus is on policy measures in basic education in the form of compulsory schooling. Basic education systems in these three countries are relatively similar. The length of the education 
varies from 9 years (Finland and Sweden) to 10 (Norway), and the age of starting school varies from 6 (Norway) to 7 (Finland and Sweden). In all three countries, most students continue their schooling in upper secondary education. The percentage of young people not in education or training in the 15-19 age group (NEET) is below the average of OECD, being 2.8 in Norway; 3.5 in Sweden and 5.2 in Finland (OECD 2017).

The history of schooling of Roma and Travellers in Finland, Sweden and Norway is tied to the stigmatised and subordinated positions of the Roma and Traveller groups within each of these societies. Education has been used to eradicate Romani languages and cultures (Engebrigtsen 2015; Lund 2010; Pulma 2006; Rodell-Olgaç 2006; 2013; Selling 2014). The groups have been excluded from education and have been subjected to assimilation efforts through education (Engebrigtsen 2015; Lund 2010; Pulma 2006; Rodell-Olgaç 2006). Roma and Travellers have been perceived as deficit groups who need to be "normalised" by schooling, the families and their cultures having been portrayed as problematic for schools and societies (Pulma 2006).

Currently, the educational experiences, paths and outcomes of students who identify as Roma or Travellers in Finland, Sweden or Norway are distinctive. In all three countries, the number of Roma and Traveller pupils who do not graduate from basic education and who do not apply for secondary education is estimated to be higher than the average for the population (Arbeidsog inkluderingsdepartementet 2009; MSAH 2009; NOU 2015; SOU 2010). Prejudice, racism and negative attitudes towards Roma and Traveller pupils as well as bullying have been reported (Junkala \& Tawah 2009; NOU 2015; Rajala et al. 2011; Rajala \& Blomerus 2015; SOU 2010).

Finnish, Swedish and Norwegian basic education is governed by education acts. In Finland, the Basic Education Act (628/1998) mentions the Roma on two occasions, both times in connection 
with the Romani language: the language of instruction in school can be Romani ( $\$ 101$. ss.628/1998), and the parent and carer can decide whether the pupil should learn Romani as the mother tongue (§12 2. ss.628/1998). The Swedish Education Act (2010:800) states that a pupil who belongs to a national minority has the right to learn the mother tongue in the pupil's own national minority language. In contrast, the Norwegian Education Act (17 July 1998, no. 61) does not mention Roma or Traveller minorities. Language minorities are only mentioned in section 2-8 of the Education Act, according to which pupils "who have a mother tongue other than Norwegian or Sami" can have "adopted education in Norwegian" until they are able to follow the general instruction in the language of the school (section 2-8).

\section{Analysing problem representations in policies}

Our interest in analysing Roma, Traveller and education policies with a specific focus on policy measures has grown out of an initial observation of an intrinsic ambivalence, even conflicting perspectives present in the policies concerned with Roma and Travellers. As critical education researchers we felt that these discrepancies required further attention. Our analysis is guided by post-structural critical policy analysis, which investigates ontological and epistemological presuppositions within policies (Bacchi 2000; 2010). A critical concept for post-structural approaches is that of discourse, which is understood as a specific structure of "statements, terms, categories and beliefs" that are bound "historically, socially and institutionally" (Scott 1988, pp. 33). Discourses set limits on thinking and acting (Bacchi 2010; Foucault 1972; St Pierre 2000). Entangled in discourse is power and the potential for subject constitution, i.e., subjectification (Butler 1997; Foucault 1980). Through discourse, the individual is rendered a subject and is subjected to power relations (Davies 2006; Youdell 2006). 
Policies, which are normative by definition, contain and produce both a "diagnosis" of the current problems and solutions to these problems. Accordingly, they produce positions and relations within nation-states and welfare states (Bacchi and Goodwin 2016). Carol Bacchi (2009; 2010; Bacchi and Goodwin 2016) has developed an analytical approach called "What's the problem represented to be?" (WPR) for post-structural policy research. In WPR analysis, the operative question is what is constituted as a problem by the policy. The "presuppositions" or "assumptions which underlie the problem representation" are investigated (Bacchi and Goodwin 2016, 20). However, since these problem representations are always constituted within wider societal discourses, the way in which the representation of the problem was initially created also needs to be addressed. The analysis also extends to examine boundaries of the problem representations, by asking what is left undiscussed by the ways the problems are represented. This opens up ways to ask whether and how the problems could be thought over otherwise (Bacchi and Goodwin 2016).

\section{Data and analysis}

In order to define the dataset for our analysis, we first mapped the key policy documents concerning national minority Roma and Traveller groups country by country, focusing on those sections that specifically discuss basic education. Similarly, with the educational policy documents, we started by mapping the legislation and national policy documents that direct basic education, focusing on sections discussing national minorities or, more specifically, Roma and Traveller groups. We narrowed down the data to include only central national documents that direct local practices and policies. This way we excluded such things as materials produced 
in various development projects focusing on Roma, Travellers and schooling. We used the official English translations of the documents as presented in Table 1 and Appendix $1 .{ }^{7}$

Our analysis focuses specifically on the policy measures promoted in basic education. From Finland, we included The Proposal of the Working Group for a National Policy on Roma [FS]. The working group proposal is a detailed document containing six key areas, ten policy guidelines and 147 measures. Basic education is mostly treated in the key area Enhancing the participation in education of Roma children and youth on all levels. From Sweden, The coordinated long-term strategy for Roma inclusion 2012-2032 [SS] was included in the data. One of its seven sections, entitled "Education", specifies measures directed to basic education.

The scattered nature of Norwegian Roma and Traveller policy documentation made framing the data challenging. We ended up analysing sections that discuss basic education from three Norwegian documents: 1) the white paper on national minorities entitled National minorities in Norway: about state policy on Jews, Kvens, Roma, Travellers and Forest Finns [NmN], 2) Action plan for improvement of the living conditions of Roma in Oslo $[\mathrm{APR}]^{8}$, and 3) the green paper on Traveller policy entitled Assimilation and Resistance: Norwegian policies towards Tater/Romani people from 1850 to the present [AaR].

In education, the national core curricula are the key policy documents after the education acts, translating their policies into practical targets and measures. Our data includes the Finnish National core curriculum 2014 [FCu], the Swedish Curriculum for the compulsory school,

\footnotetext{
${ }^{7}$ We have read most of the policy texts in their original languages. However, the official English translations are used in the text. (see Appendix 1).

${ }^{8}$ The action plan, released in 2009 , does not have any specific measures directly targeting basic education or intended to promote better educational outcomes for the pupils who are in basic education right now, but it does provide descriptions of the situation of the Roma in education. Additionally, some of the policy measures can be considered as intended to support the basic education of Roma children indirectly.
} 
preschool class and the leisure-time centre 2011 (revised 2016) [SCu] and the Norwegian

National curriculum for knowledge promotion, which applies to primary and secondary education $[\mathrm{NCu}] .^{9}$

We initially read through the Roma and Traveller policy documents to determine the measures the documents suggest for basic education and Roma and Traveller groups. We listed these measures and, following WPR-approach, asked to what kind of problem representation(s) the measure in question responds. We then read through the key national educational policy documents to identify the contexts in which the Roma and Traveller groups or national minorities are discussed. After this, we listed the sections discussing Roma and Travellers, and defined the topics in relation to which these groups are discussed. Finally, we analysed the problem representations to which these specific policies are responding. As a result three recurrent problem representations were identified: special needs of Roma children, Roma families and national minority cultures in schools.

[Table 1. near here]

\section{Problem representation 1: Special needs of Roma pupils}

In Finland, the measures introduced in the Roma policy to tackle the problems related to schooling are consistently concerned with providing Roma pupils with special support in different ways. This indicates that a common representation of the problem is that Roma

\footnotetext{
${ }^{9}$ Finland has a national core curriculum and a core curriculum for adults in basic education. Sweden has four other curricula in basic education in addition to that included in our data. These focus on learning disabilities, special schools, Sami schools and adult education. Norway also has a Sami national curriculum for knowledge promotion. In relation to Roma and Traveller minorities, these curricula do not differ greatly from the curricula chosen for the data. We have analysed the core curriculum and subject curricula of the Norwegian curriculum for knowledge promotion, leaving out the quality framework, distribution of teaching hours per subject, and individual assessment.
} 
children have special needs. In the Finnish Roma policy, Roma children are described as having particular difficulties in learning:

The key areas in the development of Roma children's education are enhancing their mastery of Finnish/Swedish and mathematical and fine motor skills. Accordingly, special attention should be paid to them from the very start of each Roma child's school education (FS, 44).

By stating that "the key areas in the development of Roma children's education" are those of "enhancing ... skills" the above extract firstly positions the student, not the school, as the focus of action. Secondly, the extract provides a homogenising description of the Roma pupils that construes them as a group having specific problems with learning. In the school context in general, the notion of "special needs" usually refers to individualised needs related to different diagnosed learning difficulties or disabilities (e.g., Arnesen, Mietola \& Lahelma 2007). However, in this case problems with the Finnish or Swedish language, mathematics and fine motor skills are constructed as characterising a group of pupils based on their ethnicity. This represents the Roma children as deviating as a group from the majority of children or from the norm (see also Lappalainen 2006, 12), as well as a homogeneous group who share the same language, mathematical abilities and fine motor skills owing to their ethnicity.

Although the Swedish Roma policy does not provide similar essentialising descriptions of Roma pupils, it does insist that schools need more information about the needs of Roma pupils and how to support these children. The measures aim at providing more knowledge about Roma children: 
A more systematic and continuous knowledge-gathering process is therefore needed to obtain a better picture of the situation and of the needs of Roma children $^{10}$ in order to identify the measures that need to be taken. (SS, 28)

There is currently a risk that knowledge acquisition by Roma pupils in years 1-6 will be hampered by a lack of support, and that gaps in knowledge will arise that are hard to bridge. (SS, 29)

[T]here is a need to review how the schools are adapting their teaching in line with the goal statements and what forms of support are being offered to Roma pupils. $(\mathrm{SS}, 29)$

The Swedish excerpts suggest that Roma children have needs that need to be mapped in order to identify the right measures to adopt. The text constructs the Roma pupils as the focus of attention by referring to the needs of Roma children and to the intensified support they need in schools. The text, however, differs from the Finnish Roma policy. While the Finnish policy describes Roma pupils as a group of children who have specific problems, the Swedish Roma policy programme only assumes that there are needs to be recognised. In the last excerpt it is also suggested that there is a need to map the support the schools are currently giving to Roma children. This formulation may open up space to examine the types of support the schools are organising for Roma children and whether the support meets the support needs of the students. In addition, the Swedish measure states that the knowledge gathered should include information concerning the general level of education of Roma pupils, such as whether they have completed compulsory education. Thus, the measure also aims at surveying the educational outcomes of

\footnotetext{
${ }^{10}$ Highlighted by the authors.
} 
Roma pupils in municipalities. Such surveys have already been conducted in Finland (see FNBE, 2004; Rajala et al., 2011).

The three Roma and Traveller policy texts from Norway differ from each other as well as from the Finnish and Swedish ones. Neither the general minority policy in Norway nor the green paper on Traveller policy suggest that the Roma and/or Traveller pupils would need special support. However, the Norwegian policy on the Roma minority resembles the Finnish and Swedish Roma policies. Although, the measures outlined in Norwegian policy on the Roma minority do not target basic education, the text contains a description of the current situation in primary and lower secondary education based on previous experiences from actions taken by the municipality and schools in Oslo. The tone of the text differs from the Finnish and Swedish documents in general, as it is based on the experiences of schools and discussions with the school personnel. Thus, the problem representations provided remain somewhat undetermined. However, similar concerns to those in Finnish and Swedish documents in relation to the study/learning skills of the Roma students and their related support needs are raised. On the basis of discussions that have taken place with the Oslo schools, the following is being reported:

According to the head teachers, instruction must often be specially adapted for Roma children. Emphasis is placed on instruction on basic skills, particularly reading and writing. This applies to instruction in Norwegian, not Romanes. ${ }^{11}$ It is also important that there are funds available for a support framework to ensure that children come to school. There is uncertainty regarding whether Roma children should be placed in separate schools/classes or whether they should attend the school closest to where they live. There are also differing views as

\footnotetext{
11 The Romani language of the Norwegian Roma group is called "Romanes".
} 
regards whether guidelines for absence and home schooling should be the same as those [rules] that apply to other pupils. The possibility of providing Romanes instruction should nevertheless be considered, but it is difficult to obtain teachers with necessary competence. (APR, 27)

As possible solutions for the current situation, the excerpt mentions a support framework for school attendance, instruction in the Romani language, separate Roma classes or schools and provision of separate guidelines concerning the absence and home schooling of Roma children. Through these depictions, the text constructs the Roma pupils as the focus of attention. However, the text provides multiple lines of interpretation concerning the causes of the special attention the Roma pupils require. These reasons include the tradition of travelling, lack of trust between home and school and the limited Norwegian language skills of the Roma pupils. The relationship between the problems and solutions discussed is thus ambiguous: for example, are separate schools or classes considered in order to provide teaching in the Romani language? Or are separate classes or differing guidelines for absence and home schooling entrusted to possibly resolve some other issues related to the schooling of Roma children, such as travelling or "special needs"? ${ }^{12}$ Thus, it remains unclear on what grounds the head teachers are discussing about the various measures.

\section{Problem representation 2. Roma families}

\footnotetext{
${ }^{12}$ In several European countries, including Finland, there has been a tendency to educate Roma pupils in segregated schooling arrangements, such as special education classes. The segregated schooling has often been found to be discriminatory and exclusive in practice (O’Nions 2015; Niemi, Mietola and Helakorpi 2010). However, good experiences have been reported from a Roma class taught by Roma teachers in both the Swedish and the Romani languages in Stockholm (Rodell Olgaç, Demetri, Dimitri-Taikon, 2010; www.romakulturklass.com).
} 
The policy measures presented in the national Roma policies are validated by assertions concerning Roma parents and families. One frequently made remark is lack of education among Roma adults and general absence of a tradition of education among the Roma. According to our analysis, the portrayal of inadequacies in parenting is stressed, particularly in the Finnish and Swedish strategies. The Norwegian policies provide both similar and different depictions.

Especially in the Finnish policy programme, most of the measures rely on the idea that there is a need to compensate for the inability of the families to support the pupils' schooling.

As many Roma parents lack the ability to support their children in their studies, special support for learning skills and abilities is needed especially in schools. (FS, p. 43)

In some cases, learning difficulties may have an impact on Roma pupils' school performance. This is usually caused by impaired learning readiness which is the result of insufficient participation in early childhood education and the parents' lack of resources in supporting their children's learning. (FS, p. 44)

In these two excerpts, the parents are described as lacking abilities or resources to support their children in school. The parents' shortcomings are represented as causing problems which need to be tackled through special support provided for the pupils. We thus read that the Roma are portrayed as lacking the prerequisites to take part in the school institution (see also Araújo 2016; Picker \& Roccheggiani 2014). 
The Swedish Roma policy depicts Roma parents slightly differently, as being hesitant about schools. This is described as causing problems for their children. The strategy states that "measures to increase the likelihood of parents wanting to support their children's education are very important" (SS, p. 27). This implies that instead of being unable to support their children, the parents might be unwilling to do this. The parents are also described as "being afraid of losing their children to mainstream society" (SS, p. 25), and feeling "that it is futile to go to school if this will not lead to employment in any case, because of direct or indirect discrimination" (SS, p. 25). Workers with a Roma background are expected to "help to ensure that parents feel more comfortable having their children in the school" (SS, p. 30). Thus, while in the Finnish Roma policy parents are mostly described as simply not capable of supporting their children, the Swedish strategy suggests that there is unwillingness among Roma parents to support their children's education. Furthermore, the Swedish Roma parents are repeatedly described in terms of emotions such as fear and comfort. The policies position the Roma parents and their feelings as targets of the suggested measures. We find, thus, that in the Swedish strategy the Roma parents are described as making decisions emotionally rather than "rationally". Associating such a number of emotions with Roma adults may result in diminishing the parents and questioning their authority in relation to schooling (Tuori 2007). This turns the focus of the measures from discrimination or racism towards the feelings of Roma individuals. In this context topics such as bullying are reduced to Roma's feelings that need to be dealt with.

The problems and measures suggested in the Action plan for improvement of the living conditions of Roma in Oslo seem to repeat conceptions of Roma parents similar to those in the Finnish and Swedish strategies: 
It is hoped that, by ensuring the basic competence of the parent generation, it will in the long term be possible to improve attendance and completion of the compulsory primary and lower secondary school by Roma children. (APR, p. 33)

The Government aims to provide satisfactory educational programmes for all children, including Roma. However, many Roma are anxious that their children will be bullied at school and in the day care owing to their ethnic background. The experience of Sweden, among other countries, shows that teaching assistants of Roma background in schools and day care institutions help to alleviate this anxiety, while providing valuable role models for the children. (APR, p. 34)

In the first excerpt, the problem underlying the educational outcomes of pupils is the lack of the "basic competence" of the parents. In the second excerpt, the parents are described as feeling anxiety about schools and day-care institutions. The proposed solution for Norwegian Roma parents' fear of bullying is to provide schools with Roma workers, whose presence in school should make the parents feel safe. In the text, bullying is not treated as a real, rational threat as much as merely a fear held by parents.

One measure promoted for basic education in each of the Roma policies is to train and recruit Roma mediators, a measure that the European organisations also promote extensively (see, e.g., http://coe-romed.org/; Helakorpi, Lappalainen \& Sahlström, in press). The presence of Roma mediators in schools is expected to solve a variety of problems. However, several of the arguments for the use of Roma mediators allude to problems connected to the relationship between the Roma parents and schools, such as the aforementioned parental fears about schools. For instance, a recurring notion in the documents is that Roma pupils do not have role models, 
a notion which can be interpreted as suggesting a lack of Roma in power positions in society owing to past and present discrimination. However, it also implies that none of the adults in the pupils' lives can be considered as suitable role models. Thus, we find that this formulation again invokes a representation of deficient Roma families.

Even though the Norwegian green paper on Traveller policy does not contain specific measures, the descriptions of Traveller parents follow the same tendencies as the Roma policies presented above in that parents are described as sceptical of schools. For instance, parents are depicted as being afraid that their children will be bullied and that schools will have different goals for their upbringing than the families (AaR, p. 107-108). However, owing to the nature of the text, it remains open whether the problem is perceived to be the feelings of the parents or the bullying and the possibility of differing goals of upbringing.

\section{Problem representation 3. National minority cultures in schools}

All the analysed documents discuss Roma and Traveller cultures in manifold ways and constitute them as a focus of policy measures. The policy measures represent the relationship between national minority cultures and schools as in need of attention. The notions concerning Roma and Traveller cultures in the policies are ambivalent: while culture is represented as problematic, it is also represented as a resource to be preserved by schools.

In the following three subchapters we firstly discuss the notion of lack of knowledge concerning Roma and Traveller cultures in schools. This notion is repeated in all of the analysed documents. We then move on to analyse notions concerning problematic cultural traditions. This representation is particularly stressed in the Swedish and Norwegian Roma and Traveller 
policies. The third subchapter focuses instead particularly on the analysed education policy documents, and how the Finnish and Swedish curricula represent Romani languages and cultures as a resource which need to be supported in the schools.

\section{Knowledge about Roma and Travellers for all}

All the analysed policies propose measures related to (the need of) providing knowledge about Roma and Travellers in school. Not only do teachers and other professionals require up-to-date information concerning Roma pupils and families (e.g. special needs, education level), the schools are also represented as having a key position in the society in providing information to students about the national minorities. This necessary knowledge is characterized in the Roma policies and the green paper on Traveller policy as "information on Romani culture and the history and conditions of the Roma minority" (FS, p. 46); "[information] describing and illustrating Roma history, culture, language, etc." (SS, p. 32); "information and guidance materials on the Roma as a minority in a multicultural society" (APR, p. 36) or "about the history and culture of Travellers" (AaR, p. 109). The policies proclaim that such knowledge is needed for teachers, teacher educators, and other pupils in order to promote equality in schools. In the national curricula providing students with information concerning national minorities is mentioned as part of the subject content in subjects such as social sciences and history.

In Finnish and Swedish Roma policies, the notion of knowledge contain a demand for schools to preserve the Romani language and culture. 
An important prerequisite for Roma people to be treated with respect and understanding and to be able to preserve their culture and their language is increased knowledge about the Roma. (SS, p. 31)

As in the above excerpt from Swedish Roma policy, both the Finnish and Swedish Roma policy documents set two interlinked tasks for the knowledge concerning Roma. On the one hand, the Roma policies state that for the Roma to be treated with respect, there is a need for increased knowledge about them. On the other hand, the school is represented as the place where the culture and language of the Roma are to be preserved. Thus, the problem that the Finnish and Swedish policies also respond to is the endangerment of the Romani language and culture. This follows the aims of international minority rights protection.

The analysed texts seem to assume that the increased knowledge will as such lead to respect, equality or enhancement of "the realization of the individual educational rights of Roma children" (FS, p. 46). None of the policy texts address further what this knowledge is, how it should be used or who generates it.

\section{Cultural traditions as a problem}

As discussed above, the Roma policy documents position Roma cultures as in need of protection; however, the same documents also portray Roma culture, in particular some traditions that the cultures are represented to keep up, as problematic. Particularly the Swedish and Norwegian Roma and Traveller policies suggest that there are cultural traditions that hinder school attendance of Roma and Traveller pupils. The Swedish Roma policy states that the

pupils' absences from school are partly explained by "certain customs and practices such as 
child marriage and early pregnancies" (SS, p. 25). Concern about child marriages and early pregnancies is brought up in relation to the topic of girls attending school. The policy also states that:

According to the UN's international convention on economic, social and cultural rights, Sweden has a responsibility to prevent parents from keeping their girls home from school. (SS, p. 28)

This representation of "girls who need to be rescued by society" is a discourse commonly used also in relation to families of migrant backgrounds (Keskinen, 2009). We find that these notions represent Roma families and cultures as patriarchal and unequal. The descriptions also contribute in portraying the Roma parents and families as hindering school attendance and the Roma girls as victims of their culture and customs.

In Norway, each of the texts with the exception of the curriculum discusses the travelling of Roma and Travellers. It remains unresolved how the issue of their travelling should be addressed vis-à-vis children's schooling.

It is a major wish of the Roma community that their children shall go to school, but that schooling should be adapted to the situation of the Roma and to the fact that many travel for parts of the year. It is not clear how far the school should go to meet wishes for culturally adapted education, nor is any clear answer given by the Council of Europe's Framework Convention or the Council of Europe's recommendations on education and the Roma. The Ministry of Education and 
Research will launch a study to clarify the relationship between Norwegian and international law in the area of education. (APR, p. 43)

The excerpt discusses how far the schools should accommodate the right of the minority to pursue their tradition of travelling. There have been projects in Norway intended to resolve this by, for instance, providing education with the help of computers when the pupils are travelling (see, e.g., Lund 2010). Likewise, the Norwegian minority policy from 2000 (NmN, pp. 7; 57) states that there may be a need to develop forms of education and learning which can take place when Roma or Traveller families are on the road. Despite these discussions, the Norwegian documents describe the tradition of travelling as a problem for school attendance and the excerpt discusses whether the schools should find ways of teaching pupils who are travelling with their families. It remains ambiguous, however, whether the problem lies with the tradition or with schools that are unable to educate pupils who travel.

\section{Romani language and culture as a resource}

The Finnish and Swedish curricula foreground the idea of preserving Romani culture through preserving the Romani language. As previously described, in Finland and Sweden the national basic education acts provide people belonging to Roma minorities the right to study Romani language as mother tongue. As a result, the Swedish and Finnish national curricula include Romani language syllabi for mother tongue for Roma pupils. In these specific syllabi the Romani language and culture are strongly represented as resources which should be preserved.

Languages are important bearers of culture that express the common experiences, values and knowledge which unite the national minorities in Sweden with the 
people who speak the same language in other parts of the world. Knowledge of the language and the minority culture can provide new perspectives on one's own identity and strengthen opportunities to participate in society in Sweden and other countries. (SCu, p. 134)

In the above excerpt from the Swedish curriculum, language is described as a resource that unites people both in Sweden and in other parts of the world. Language is also connected to culture, values and experiences. In the same excerpt, language is further tied to identity work. In the Finnish Romani mother tongue syllabus, the endangered status of the Romani language is discussed, and the children are expected to learn to acknowledge their role in preserving it (FCu, p. 460). The Finnish curriculum also states that learning Romani will improve the selfesteem of the pupils and motivate them in school (FCu, p. 456). The Romani languages and cultures are thus represented as having a vulnerable position in society and as valuable resources for Roma pupils.

As previously discussed, the Norwegian Basic Education Act takes a very different stance in relation to the right of minorities to have teaching/instruction in their own language. The National Curriculum for Mother Tongue Teaching for Language Minorities (p. 2) clarifies this by stating that "the curriculum for mother tongue teaching for language minorities is a transitional plan", meaning that the students whose mother tongue is something other than Norwegian or Sami have not been given the right to receive teaching in their mother tongue or to study their mother tongue. There is no mention of the Roma and Traveller minorities in the Education Act or in the National Curriculum. In terms of language teaching, the right of the Roma students as a national minority to receive teaching in their mother tongue is similar to those of students coming from other language minorities, often with a migrant background. 


\section{Conclusions}

In this article we have examined policies intended to promote the basic education of Roma and Traveller minorities in Finland, Sweden and Norway by analysing national Roma and Traveller policies as well as education policies. The analysis of Roma policies shows how the policies translate the general policy aims of human rights and minority rights consistently into policy measures responding to the special needs of Roma pupils. These policy measures are in turn validated by problem representations regarding Roma parents and families. The Norwegian green paper on Traveller minority suggests representations both differing from and similar to the Roma policies: while the Traveller pupils are not represented as in need of special support in the schools, the text describes Traveller parents as cynical and having fears about the school system. However, since the concerned text is only a background report, it is not clear what kind of focus the actual policy measures would take.

All the analysed policy documents bring into focus and problematises the relationship between Roma and Traveller cultures and schools. However, the education policies differ from the Roma and Traveller policies. Whereas the Roma and Traveller policies present ambiguous remarks on the relationship between the cultures and schools, the Finnish and Swedish education policies take a stance on promoting the Romani language and culture(s). In the form of Romani mother tongue syllabi, the curricula highlight the minority rights agenda, emphasising the position of the language and culture in the societies. However, outside the Romani mother tongue syllabi, the notions of Roma are scarce. The Norwegian education policy processes are distinct from the Finnish and Swedish ones in not promoting the mother tongue learning of these minorities. 
The Roma and Traveller policy programmes analysed here have originated from the general policy commitment to promote human rights and improve the social positioning of people identifying as Roma or Travellers. Historical and current discrimination is acknowledged in the policies, as well as the groups' rights to their own culture and languages. Our analysis of Roma policy documents however suggests, that while these general policy commitments are articulated in the policy documents, the perspective that the policy measures take, rather problematise the Roma and their relationship to the school than the oppressive structures and practices that have resulted to their marginal positioning.

What remains mostly undiscussed in the analysed documents and untouched by the specific policy measures are the mechanisms that cause the Finnish, Swedish and Norwegian schools to fail in providing sufficient education for each child, regardless of the background of the child. Instead of representing the Nordic schools as failing in terms of equality, the policy measures focus on minority pupils and their parents who are portrayed as lacking resources in relation to the schools (see also Beach \& Sernhede 2011). Bullying in school and discrimination in the labour market faced by Roma are approached through fears and feelings of the parents. The analysed documents seem to miss the opportunity to raise the topics of bullying and discrimination as a key focus of policy, as cultural and societal problems that need to be addressed in schools. To give pupils special support when their parents lack resources is surely a step towards preventing segregation of the children and providing them with equal opportunities; however, the equality work should not simply target the Roma and Traveller groups, but also those structures and processes that reproduce societal inequality. 
Some Roma and Traveller representatives, especially in Sweden and Norway, have raised concerns that the national policies may lead to problematic, homogenizing and victimizing descriptions of the groups (Alexiadou\&Norberg, 2017; Høring - oppfølging av Tater/romaniutvalgets rapport). Previous research has found homogenising representations of Roma and Traveller groups being widespread in Europe (Yuval-Davis, Varjú, Tervonen., Hakim \& Fathi 2017). Our analysis of the Roma policies indicate that although the policies mention that the minorities are heterogeneous, the problem representations formed in the policy measures tend to portray Roma minorities as homogeneous groups. Thus, the articulations of heterogeneity in the texts can be characterised as "non-performative" in nature (Ahmed 2006; 2012) as the basic education measures and the reasoning behind them represent the Roma in an essentialising manner.

The essentialising and homogenising descriptions do suit the logic of welfare states in constructing descriptions of "disadvantaged groups" and in trying to map out solutions to help them (Jokinen, Huttunen and Kulmala 2004); however, the descriptions may marginalize as they tend to construct Roma as needing activation or as unable to take part to the institutions (Araújo 2016; van Baar 2012b). In addition, we find that the Roma are described as groups having vulnerabilities and little resources, which in itself can be marginalising and stigmatising (Toivanen 2010; van Baar 2011). The portrayals of Roma children and families, as being in need of help, resemble the ways they have been portrayed during eras of explicit assimilation and exclusion policies (Montesino \& Ohlsson Al Fakir 2015; Pulma 2006). This clear tendency in Roma policies has also been identified by previous European research (e.g., Araújo 2016; van Baar 2012b; Montesino \& Ohlsson Al Fakir 2015). 
The danger of essentialisation is relevant also when considering the ways how Roma and Traveller cultures are represented in connection to the demands for more knowledge about Roma and Travellers in schools. The discourses of protecting the cultures may encourage essentialisation of minorities since the processes of defining what to present and what to protect in cultures imply the danger of reducing complicated histories, cultures and relations to simplistic and rigid descriptions (Anthias 2002; Vermeersch 2008). Ideas such as "elaborating on national minorities" in curricula can thus invite essentialising and homogenising descriptions of Roma and Traveller minorities. Some of the Norwegian Travellers have objected to the idea of providing knowledge about Travellers in schools (Høring - oppfølging av Tater/romaniutvalgets rapport). Thus, it would be important to discuss what this knowledge might be, how this knowledge could be used and who might be generating it (Helakorpi, forthcoming).

The analysis of the current problem representations show that there are clear limitations in addressing the marginalising mechanisms of the school systems in these Nordic welfare states. Alternative approaches could be provided by antiracist education, for instance (Alemanji 2016). In addition, the policy measures could encourage the school systems to question cultural norms (Rodell- Olgaç 2006; 2013). We find, that the current formulation of policy measures and their focus constrain change in terms of equality in education.

\section{Acknowledgments}

The work reported here was made possible through funding from the Nordic Center of Excellence Justice through Education (JustEd) at the University of Helsinki and Academy of Finland (project nr. SA 2755988). 


\section{References}

Ahmed, S. (2000). Strange encounters: Embodied Others in post-coloniality. London and New York: Routledge.

Ahmed, S. (2006). The nonperformativity of antiracism. Meridians: Feminism, race, transnationalism, 7(1), 104-126.

Ahmed, S. (2012). On being included: Racism and diversity in institutional life. Durham and London: Duke University Press.

Alemanji, A. A. (2016). Is there such a thing...? A study of antiracism education in Finland. Helsinki: Unigrafia.

Alexiadou, N. (2017). Equality and education policy in the European Union: An example from the case of Roma. In Parker, S., Gulson, K. N., Gale, T. (eds.) Policy and Inequality in Education: Volume 1. Series: Education Policy \& Social Inequality. Singapore: Springer Publishing Company, 111-131.

Alexiadou, N. \& Norberg, A. (2017). Sweden's double decade for Roma inclusion: An examination of education policy in context. European Education, (49) 1, 36-55. doi: $10.1080 / 10564934.2017 .1280342$

Anthias, F. (2002). Beyond feminism and multiculturalism: Locating difference and the politics of location. Women's Studies International Forum, 25(3), 275 - 286. 
AoI [Arbeids- og inkluderingsdepartementet]. (2009) Action plan for improvement of the living $\begin{array}{llll}\text { conditions } & \text { Roma } & \text { in } & \text { Retrieved }\end{array}$ https://www.regjeringen.no/globalassets/upload/FAD/Vedlegg/SAMI/Nasjmin/Handlingsplan _rom_EN.pdf

Araújo, M. (2016). A very 'prudent integration': White flight, school segregation and the depoliticization of (anti-)racism. Race, Ethnicity and Education. 19(2), 300-323. doi: $10.1080 / 13613324.2014 .969225$

Arbetsmarknadsdepartementet. (2014) Den mörka och okända historien: Vitbok om övergrepp och kränkningar av romer under 1900-talet. [The dark and unknown history: White Paper on abuses and rights violations of Roma during the 1900s] Stockholm: Regeringskansliet

Arnesen, A.-L., Mietola, R. \& Lahelma, E. (2007) Language of inclusion and diversity: Policy discourses and social practices in Finnish and Norwegian schools. International Journal of Inclusive Education 11(1), 97-110. http://dx.doi.org/10.1080/13603110600601034

Bacchi, C. (2000). Policy as discourse: What does it mean? Where does it get us? Discourse: Studies in the Cultural Politics of Education. 21(1), 45-57. doi: 10.1080/01596300050005493

Bacchi, C. (2009). Analysing policy: What's the problem represented to be? Frenchs Forest: Pearson. 
Bacchi, C. (2010). Poststructuralism, discourse and problematization: Implications for gender mainstreaming. Kvinder, køn \& forskning. 4, 62-72.

Bacchi, C. \& Goodwin S. (2016). Poststructural policy analysis: A guide to practice. New York: Palgrave Pivot.

Beach, D. \& Sernhede O. (2011). From learning to labour to learning for marginality: school segregation and marginalization in Swedish suburbs. British Journal of Sociology of Education, 32 (2), 257-274.

Bijvoet \& Fraurud (2007) Det romska språket och romsk språkvård i Sverige. [Romani language and language planning in Sweden] Retrieved from Institutet för språk och folkminnen: https://www.sprakochfolkminnen.se/download/18.4aec91b214565240e191055/13986883120 19/Det+romska+spr\%C3\%A5ket+och+romsk+spr\%C3\%A5kv\%C3\%A5rd+i+Sverige+2007. pdf

Brearley, M. (2001). The persecution of Gypsies in Europe. American Behavioral Scientist 45 (4), 588-599. doi: 10.1177/00027640121957367

Brubaker, R. (1996) Nationalism reframed: Nationhood and the national question in the new Europe. Cambridge: Cambridge University Press.

Bunescu, I. (2014). Roma in Europe. The politics of collective identity formation. London: Routledge. 
Butler, J. (1997). The psychic life of power: Theories in subjection. Stanford, CA: Stanford University Press.

CoE [Council of Europe] ETS No. 148. European charter for regional or minority languages. Retrieved from: http://www.coe.int/en/web/european-charter-regional-or-minoritylanguages/text-of-the-charter

CoE [Council of Europe] Treaty 157. Framework convention for the protection of national minorities. Retrieved from: http://www.coe.int/en/web/minorities/text-of-the-convention

CoE [Council of Europe]. (2000) Recommendation No R (2000) 4 of the committee of ministers to member states on the education of Roma/Gypsy children in Europe. Retrieved from: http://www.coe.int/en/web/portal/roma/

CoE. [Council of Europe]. (2016). Thematic action plan on the inclusion of Roma and Travellers 2016-2019. Retrieved 10.7.2017 from: https://rm.coe.int/1680684b5e

Davies, B. (2006). Subjectification: The Relevance of Butler's Analysis for Education. British Journal of Sociology of Education 27 (4), 425-438.

Engebrigtsen, A. I. (2015). Educating the Roma: The Struggle for Cultural Autonomy in a Seminomadic Group in Norway. Social Inclusion 3(5), 115-125.

European Commission. (2011). An EU framework for national Roma integration strategies up to 2020: Communication from the commission to the European parliament, the council, the 
European economic and social committee and the committee of the regions COM (2100) 173 final. Brussels: Commission of the European Communities.

European Union. (2012). Roma and education: Challenges and opportunities in the European Union. Luxembourg: Publication Office of the European Union.

FNBE [Finnish National Board of Education]. (2004). Romanilasten perusopetuksen tila: Selvitys lukuvuodelta 2001-2002. (A survey of the status of Roma children's basic education school year 2001-2002) Helsinki: National Board of Education.

Foucault, M. (1972). The archaeology of knowledge, and the discourses on language. (trans. Rupert Sawyer). New York: Pantheon Books.

Foucault, M. (1980). Power/Knowledge: Selected interviews and other writings, 1972-1977, edited by C. Gordon. New York: Harvester Wheatsheaf.

Gobbo, Francesca. (2015). Introduction: On the education of Roma. Interrogating research findings and institutional policies. Intercultural Education 26 (2), 87-93.

Helakorpi, J., Lappalainen, S. and Sahlström, F. (in press) Becoming tolerable: Subject constitution of Roma mediators in Finnish schools. Intercultural Education.

Helakorpi, J. (forthocoming) Negotiating narratives: Roma and Travellers challenging racialisation and descriptions of the nations in education. In Keskinen, S., Skaptadottir U. D. 
and Toivanen, M. (eds.) "Cultural Homogeneity, Difference and Securitisation in the Nordic Region" New York: Routledge.

Herakova, L. L. (2009) Identity, communication, inclusion: The Roma and (new) Europe, Journal of International and Intercultural Communication. 2(4), 279-297, doi: $10.1080 / 17513050903177318$

HL-senteret. (2012). Antisemitism in Norway? The attitudes of the Norwegian population towards Jews and other minorities. Retrieved from http://www.hlsenteret.no/publikasjoner/antisemitism-in-norway-web.pdf

Høring - oppfølging av Tater-/romaniutvalgets rapport. [Hearing - follow-up for Traveller committee report] Retrieved from: https://www.regjeringen.no/no/dokumenter/horing--oppfolging-av-tater-romaniutvalgets-rapport/id2464464/

Jokinen, A., Huttunen, L., Kulmala, A. (2004). Johdanto: Neuvottelu marginaalien kulttuurisesta paikasta. [Introduction: Negotiating the cultural space of the margins]. In Jokinen, A., Huttunen, L., Kulmala, A. (Eds.) Puhua vastaan ja vaieta (pp. 9-19). Helsinki: Gaudeamus.

Junkala, P. \& Tawah, S. (2009). Enemmän samanlaisia kuin erilaisia: Romanilasten ja nuorten hyvinvointi ja heidän oikeuksiensa toteutuminen Suomessa. [More similar than different: The well-being and the implementation of the rights of the Roma children and youth] Jyväskylä: Lapsiasiainvaltuutetun toimiston julkaisuja 2009:2 
Keskinen, S. (2009). 'Honour-related violence' and Nordic Nation-Building. In

Keskinen, S., Tuori, S., Irni, S. ja Mulinari, D. (Eds.) Complying with

colonialism. Gender, Race and Ethnicity in the Nordic Region (pp. 257-

272). Farnham: Ashgate.

Kymlicka, W. (2007). The internationalization of minority rights. International Journal of Constitutional Law, 6(1), 1-32. doi: 10.1093/icon/mom032

Lappalainen, S. (2006). Kansallisuus, etnisyys ja sukupuoli lasten välisissä suhteissa ja esiopetuksen käytännöissä. [Nationality, ethnicity and gender in children's peer relations and preschool practices] Helsinki: Yliopistopaino.

Lund, A. B. (2010). A study on how the use of ICT in travelling periods influences Romani students' attitudes towards school. Problems of Education in the $21^{\text {st }}$ Century, 26, 19-29.

Montesino, N., \& Ohlsson Alfakir, I. (2015). The prolonged inclusion of Roma groups in Swedish society. Social Inclusion, 3(5), 126-136. doi:10.17645/si.v3i5.247.

MSAH [Ministry of Social Affairs and Health]. (2009). Suomen romanipoliittinen ohjelma: työryhmän esitys. [The proposal of a working group for national policy on Roma] Helsinki: Ministry of Social Affairs and Health.

MSAH. [Ministry of Social Affairs and Health] (2016). Enhancing the visibility of the living conditions and status of the Roma in the Nordic countries [news item] Retrieved from: 
http://stm.fi/artikkeli/-/asset_publisher/romanien-elinolot-ja-asema-pohjoismaissanakyvaksi?_101_INSTANCE_yr7QpNmlJmSj_languageId=en_US

Muižnieks, N. (2015). Report. Commissioner for Human rights of the Council of Europe. Retrieved from: http://www.humanrightseurope.org/2016/04/nils-muiznieks-human-rightsannual-report-2015/

NDO [Non-Discrimination Ombudsman]. (2014). Erilaisena arjessa: Selvitys romanien syrjintäkokemuksista. [Being different in the everyday life: A report about Roma's experiences of discrimination] Julkaisusarja 15.

Niemi A.-M., Mietola, R. and Helakorpi, J. (2010). Erityisluokka elämänkulussa: Selvitys peruskoulussa erityisluokalla opiskelleiden vammaisten, romaniväestöön kuuluvien ja maahanmuuttajataustaisten nuorten aikuisten koulutus- ja työelämäkokemuksista. [Special needs education class in the life-course] (Ministry of the interior publication 1/2010). Helsinki: The Finnish Ministry of the Interior.

Nordberg, C. (2006). Integrating a traditional minority into a Nordic society: Elite discourse on the Finnish Roma. Social Work \& Society 3(2), 158-173.

Nordberg, C. (2015). Dynamics of recognition: Minority ethnic access to transformative power in the Nordic welfare state. In Kraus, P. A. and Kivisto, P. (Eds.). The challenge of minority integration (pp. 91-107). De Gruyt Open. 
NOU. [Norges offentlige utredninger]. (2015). Assimilering og motstand Norsk politikk overfor taterne/romanifolket fra 1850 til i dag [Assimilation and resistance: Norwegian policy towards Tater/Romani people from 1850 to the present] (NOU 2015:17). Retrieved from: https://www.regjeringen.no/no/dokumenter/nou-2015-7/id2414316/

OSCE. [Organization for Security and Co-operation in Europe] (2003) Decision no. 3/03 Action plan on improving the situation of Roma and Sinti within the OSCE area (mc.dec/3/03). http://www.osce.org/odihr/17554?download=true

OECD [The organisation for economic co-operation and development] (2017) Youth not in employment, education or training (NEET) (indicator). doi: 10.1787/72d1033a-en

O’Nions, H. (2015). Narratives of social inclusion in the context of Roma school segregation. Social Inclusion 3(5), 103-114. doi: 10.17645/si.v3i5.258

Picker, G. \& Roccheggiani, G. (2014) Abnormalising minorities: The state and expert knowledge addressing the Roma in Italy. Identities 21(2), 185-201. doi:

10.1080/1070289X.2013.854719

Pulma, P. (2006). Suljetut ovet: Pohjoismaiden romanipolitiikka 1500-luvulta EU-aikaan. [Closed doors. Nordic Romani Policy from the 16th century to the EU era]. Helsinki: Suomalaisen Kirjallisuuden Seura. 
Rajala, S., Salonen, M., Blomerus, S. \& Nissilä, L. (2011). Romanioppilaiden perusopetuksen tilannekatsaus 2010-2011 ja toimenpide-ehdotukset. [Basic education of Roma pupils - review 2010-2011 and proposals] (Reports 2011:26). Helsinki: National Board of Education.

Rajala, S. and Blomerus, S. (2015). Katsaus aikuisten romanien koulutustaustoihin. [A review of the educational backgrounds of adult Roma] (Reports 2015:8). Helsinki: Finnish National Board of Education.

Riitaoja, Anna-Leena. (2013). Toiseuksien rakentuminen koulussa: Tutkimus opetussuunnitelmista ja kahden helsinkiläisen alakoulun arjesta. [Constructing Otherness in school: A study of curriculum texts and the everyday life of two primary schools in Helsinki] Helsinki: Unigrafia.

Rodell Olgaç, C. (2006). Den romska minoriteten i majoritetssamhällets skola: Från hot till möjlighet. [The Roma as a minority in the mainstream schools: From a threat to a hope] Studies in Educational Sciences 85, Stockholm: HLS Förlag.

Rodell-Olgaç, C. (2013) Education of Roma in Sweden: An interplay between policy and practice. In Horneberg, S. and Brüggemann C. (Eds.) Die Bildungssituation von Roma in Europa (pp. 197-213). Münster: Waxmann Verlag.

Rodell Olgaç, C., Demetri, M \& Dimitri-Taikon, A. (2010) Nya perspektiv på romska barn skolgång. [New perspectives on the school attendance of the Roma] In Lahdenperä, P. \& Lorentz, H. (Eds.) Möten i mångfaldens skola (pp. 133-155). Lund: Studentlitteratur. 
Roma Nation and Travelers. [Declaration] Retrieved from: http://academic.udayton.edu/race/06hrights/WCAR2001/NGOFORUM/Roma.htm

Rosvoll, M. and Bielenberg, N. (2012). Antisiganisme, stereotyper og diskriminering av rom. [Antiziganism, stereotypes and discrimination of Roma] (HL-senterets temahefte nr. 14).

Scott, J. W. (1988). Deconstructing equality-versus-difference: Or, the uses of poststructuralist theory for feminism. Feminist Studies, 14 (1), 33-50.

Selling, J. (2014). Svensk antiziganism: Fördomens kontinuitet och förändringaensförutsättningar. [Swedish antiziganism] Riga: Östkultur Förslag.

SOU (Statens offentliga utredningar). (2010). Romers rätt: En strategi för romer $i$ Sverige. (report 2010:55).

SOU (Statens offentliga utredningar). (2016). Kraftsamling mot antiziganism. [Collecting forces against antiziganism] Kommissionen mot antiziganism. (report 2016:44).

St. Pierre, Elisabeth Adams. (2000). Poststructural feminism in education: An overview. Qualitative Studies in Education, (13) 5, 477-515.

Toivanen, Reetta. (2010). Rethinking the concept of effective participation: Are minorities similar to women? Journal on Ethnopolitics and Minority Issues in Europe 9 (2), 1-31.

Tuori, S. (2007). Erontekoja. Rodullistetun sukupuolen rakentuminen monikulttuurisessa 
naispolitiikassa. [Difference making: Construction of racialised genders in multicultural women's politics] In Kuortti, J., Lehtonen, M. ja Löytty, O. (Eds.) Kolonialismin jäljet. Keskustat, periferiat ja Suomi (pp. 156-174). Helsinki: Gaudeamus.

Tyldum, Guri and Friberg Jon Horgen. (2014). Et skritt på veien: Evaluering av handlingsplan for å bedre levekårene blant rom i Oslo. [First step: Evaluation of the action plan to improve the living conditions of the Roma in Oslo] (Fafo-rapport 2014:50).

UN. [United Nations] (2013). The role of United Nations in advancing Roma inclusion. Retrieved from: http://www.europe.ohchr.org/Documents/Publications/RomaInclusion.pdf

Van Baar, Huub. (2011). Europe's Romaphobia: Problematization, securitization, nomadization. Environment and Planning: Society and Space, 29 (2), 203 - 212.

Van Baar, Huub. (2012a). Towards a politics of representation beyond hegemonv neoliberalism: the European Romani movement revisited. Citizenship Studies, 16 (2), 287-296.

Van Baar, Huub. (2012b). Socio-economic mobility and neo-liberal governmentality in postsocialist Europe: Activation and dehumanisation of the Roma. Journal of Ethnic and Migration Studies. 38(8), $1289-1304$.

Weiste-Paakkanen, A., Martelin, T., Koponen, P., Koskinen, S. ja Linnanmäki, E. (2014). Romanien hyvinvointi: Esitutkimus. Loppuraportti. [Well-being of the Roma: A preliminary study. End report.] (National institute for health and welfare: 16: 2014). 
Vermeersch, Peter. (2006). The Romani movement: Minority politics and ethnic mobilization in contemporary Central Europe. New York: Berghahn Books.

Vermeersch, Peter. (2008). Exhibiting multiculturalism. Third Text, 22(3), 359-371, doi: $10.1080 / 09528820802204789$

Vermeersch, P. (2012). Reframing the Roma: EU initiatives and the politics of reinterpretation. Journal of Ethnic and Migration Studies, 38(8), 1195-1212. doi: 10.1080/1369183X.2012.689175

World Bank \& European Commission. (2015). Handbook for improving the living conditions of Roma at the local level. Retrieved 10.7.2017 from: http://coeromact.org/sites/default/files/romact_resources_files/worldbank_handbook_roma_en.pdf

Youdell, D. (2006). Subjectivation and performative politics: Butler thinking Althusser and Foucault: intelligibility, agency and the raced-nationed-religioned subjects of education. British Journal of Sociology of Education 27(4): 511-528.

Yuval-Davis, N. (1997). Gender \& Nation. London: SAGE Publications.

Yuval-Davis, N. (2011). The Politics of Belonging. Intersectional contestations. London: Sage.

Yuval-Davis, N. Wemyss, G. \& Cassidy, K. (2017): Introduction to the special issue: Racialized bordering discourses on European Roma. Ethnic and Racial Studies, doi: $10.1080 / 01419870.2017 .1267382$ 
Yuval-Davis, N., Varjú, V., Tervonen, M., Hakim, J. \& Fathi, M. (2017). Press discourses on Roma in the UK, Finland and Hungary. Ethnic and Racial Studies. doi: http://dx.doi.org/10.1080/01419870.2017.1267379 


\section{Appendix 1. The data}

\section{Finland}

MSAH (Ministry of Social Affairs and Health). 2009. Suomen romanipoliittinen ohjelma: työryhmän esitys. Helsinki: Ministry of Social Affairs and Health. Retrieved from: https://www.julkari.fi/handle/10024/112356

MSAH (Ministry of Social Affairs and Health). 2009. The Proposal of the Working Group for a National Policy on Roma. Working group report. Helsinki: Ministry of Social Affairs and Health. Retrieved from: https://www.julkari.fi/handle/10024/126371

Perusopetuslaki. 21.8.1998/628 [Education Act] Retrieved from: http://www.finlex.fi/fi/laki/ajantasa/1998/19980628

Perusopetuksen opetussuunnitelman perusteet 2014. [Core curriculum for basic education 2014.] Opetushallitus. Määräykset ja ohjeet 2014:96. Retrieved from: http://www.oph.fi/download/163777_perusopetuksen_opetussuunnitelman_perusteet_2014.pd f

\section{Sweden}

Regeringens skrivelse 2011/12:56 En samordnad och långsiktig strategi för romsk inkludering 2012-2032. Retrieved from: http://www.regeringen.se/rattsdokument/skrivelse/2012/02/skr.20111256-/ 
Government communication 2011/12:56 A coordinated long-term strategy for Roma inclusion $2012-2032$ Retrieved from: http://ec.europa.eu/justice/discrimination/files/roma_sweden_strategy_en.pdf

Skollag. 2010:800. [Education Act] Retrieved from: http://www.riksdagen.se/sv/dokumentlagar/dokument/svensk-forfattningssamling/skollag-2010800_sfs-2010-800

Läroplan för grundskolan, förskoleklassen och fritidshemmet 2011. Reviderad 2016. [Curriculum for basic education, pre-school and the leisure-time centre 2011. Revised 2016] Skolverket. Retrieved from: https://www.skolverket.se/om-skolverket/publikationer/visaenskildpublikation?_xurl_=http $\% 3 \mathrm{~A} \% 2 \mathrm{~F} \% 2 \mathrm{Fwww} 5$. skolverket.se $\% 2$ Fwtpub $\% 2$ Fws $\% 2$ Fskolbok $\% 2$ Fwpubext\%2Ftrycksak\%2FRecord\%3Fk\%3D2575

\section{Norway}

Det Kongelege kommunal- og regionaldepartement. St.meld.nr. 15 (2000-2001) Nasjonale minoritetar I Noreg - Om statleg politikk overfor jødar, kvener, rom, romanifolket og skogfinnar. Tilråding frå Kommunal- og regionaldepartementet av 8. desember 2000, godkjend i statsråd same dagen [National minorities in Norway: state policy on Jews, Kvens, Roma, $\begin{array}{lllll}\text { Traveller and Forest from: } & \text { Finns }\end{array}$ https://www.regjeringen.no/no/dokumenter/stmeld-nr-15-2000-2001-/id585195/ 
NOU. [Norges offentlige utredninger]. (2015) Assimilering og motstand Norsk politikk overfor taterne/romanifolket fra 1850 til i dag [Assimilation and resistance: Norwegian policy towards Tater/Romani people from 1850 to the present]. NOU 2015: 17. Retrieved from: https://www.regjeringen.no/no/dokumenter/nou-2015-7/id2414316/

Arbeids- og inkluderingsdepartementet. (2009) Handlingsplan for å bedre levekårene for rom i Oslo. Retrieved from: https://www.regjeringen.no/no/tema/urfolk-og-minoriteter/nasjonaleminoriteter/midtspalte/Handlingsplan-for-a-bedre-levekarene-for-rom-i-Oslo/id594323/

Arbeids- og inkluderingsdepartementet. (2009) Action plan for improvement of the living conditions of Roma in Oslo. Retrieved from: https://www.regjeringen.no/globalassets/upload/FAD/Vedlegg/SAMI/Nasjmin/Handlingsplan _rom_EN.pdf

Education Act. Act of 17 July 1998 no. 61 relating to Primary and Secondary Education and Training (The Education for . https://www.regjeringen.no/contentassets/b3b9e92cce6742c39581b661a019e504/educationact-norway-with-amendments-entered-2014-2.pdf

Core curriculum for primary, secondary and adult education in Norway. The Royal Ministry of Education, Research and Church Affairs. Retrieved from: https://www.udir.no/globalassets/filer/lareplan/generell-del/core_curriculum_english.pdf

\section{Syllabi for individual subjects}


Norwegian subject curriculum (NOR1-05). Retrieved from: https://www.udir.no/k106/NOR105?lplang=eng

Curriculum for mother tongue teaching for language minorities (NOR8-01). Retrieved from: https://www.udir.no/k106/NOR8-01 ?lplang=eng

Curriculum for basic Norwegian for language minorities (NOR7-01): https://www.udir.no/k106/NOR7-01?lplang=eng

Curriculum for knowledge of Christianity, religion, philosophies of life and ethics (RLE1-02). Retrieved from: https://www.udir.no/k106/RLE1-02?lplang=eng

Social studies subject curriculum (SAF1-03). Retrieved from: https://www.udir.no/k106/SAF103?lplang=eng 